\title{
Production of sweet corn milk yogurt using Lactobacillus casei
}

\author{
Huynh Xuan Phong ${ }^{l}$,Phan Le Bao Ngoc $^{l}$, Nguyen Ngoc Thanh ${ }^{l}$, Bui Hoang Dang Long ${ }^{l}$, \\ Tran Thanh Truc ${ }^{2,3}$, and Tran Thi Yen $\mathrm{Nhi}^{4,5^{*}}$ \\ ${ }^{1}$ Biotechnology Research and Development Institute, Can Tho University, Can Tho City, Vietnam \\ ${ }^{2}$ College of Agriculture, Can Tho University, Can Tho City, Vietnam \\ ${ }^{3}$ School of Graduate, Can Tho University, Can Tho City, Vietnam \\ ${ }^{4}$ Institute of Environmental Sciences, Nguyen Tat Thanh University, Ho Chi Minh City, Vietnam \\ ${ }^{5}$ Faculty of Environmental and Food Engineering, Nguyen Tat Thanh University, Ho Chi Minh City, \\ Vietnam,
}

\begin{abstract}
This study aimed to produce a new functional fermented food product from sweet corn milk yogurt using Lactobacillus casei. The suitable conditions for lactic acid fermentation in sweet corn milk were investigated, including initial bacterial concentration, ratio of sweet corn milk and cow milk, sugar concentration, fermentation time and temperature. The results showed that the appropriate conditions for sweet corn milk yogurt production as follow: initial bacterial concentration was 106 cells $/ \mathrm{mL}$, fermentation time was $12 \mathrm{~h}$ at $37^{\circ} \mathrm{C}$ and sweet corn milk was fortified with cow milk at a ratio of $2: 8$ and $12 \%$ of sugar. The sweet corn milk yogurt was slightly yellow, smooth texture and thick body with the aroma of corn and acidic smell. The product remained acceptable taste and texture within 4 weeks at $0^{\circ} \mathrm{C}$ and 2 weeks at $5^{\circ} \mathrm{C}$.
\end{abstract}

\section{Introduction}

Yogurts are important elements of the human diet, due to their high nutritional value and their appealing sensory properties [1]. Yogurt is one of the most popular fermented dairy products and its consumption is increasing worldwide [2]. According to the Euromonitor database, the yogurt production in 2015 reached 27.7 million metric tons, a 1.2-fold increase compared with the yield in 2010 [3]. Yogurt appeared a long time ago and principally made from cow's milk by acid lactic fermentation [4]. Yogurt has the source of proteins, vitamins, and minerals (especially calcium, vitamin B2, B6, B12) [5-6]. Yogurt is defined as the product being manufactured from milk (with or without the addition of some natural derivative of milk, such as skim milk powder, whey concentrates, caseinates, cream with a gel structure that results from the coagulation of the milk proteins, due to the lactic acid secreted by defined species of bacterial cultures [7].

\footnotetext{
$\overline{{ }^{*} \text { Corresponding author:ttynhi@ntt.edu.vn }}$
} 
Considerable knowledge has been accumulated on the lactic acid bacteria (LAB) that affect the aroma and flavor of yogurt [8]. The predominant organisms in these starter cultures are lactic acid bacteria, for example, Lactococcus lactis, Lactobacillus species, Streptococcus thermophilus, Bifidobacterium species, and Leuconostoc species [9]. Lactobacillus casei is a strain with satisfying technological characteristics and therefore has numerous applications in the production of food products such as cheese [10], sausages [11], fermented milks [12], and yogurts [13, 14].

Nowadays, fresh fruits, fruit juices or cereals were added in yogurt to vary the food resources and improve the nutritional value of yogurt, such as carrot [6], banana [15], mango, and papaya [16]. Combining the intake of yogurt and fruit could provide probiotics, prebiotics, high-quality protein, important fatty acids, and a mixture of vitamins and minerals that have the potential to exert synergistic effects on health [17]. Corn is being cultivated worldwide for its demand as a high energy, micronutrient rich value-added food and it is being used by developing countries for food production while developed countries use it for industrial purposes $[18,19]$. Sweet corn contains 5-6\% sugar, 10-11\% starch, 3\% water-soluble polysaccharides and $70 \%$ water, besides moderate levels of protein and vitamin (yellow varieties) and potassium [20]. Sweet corn contains significant amount of lutein, zeaxanthin, and other carotenoids [21]. Sweet corn was reported to contain $75.7 \%$ moisture, $6.8 \mathrm{mg} / 100 \mathrm{~g}$ vitamin $\mathrm{C}, 2.0 \mathrm{mg} / 100 \mathrm{~g}$ calcium, $37 \mathrm{mg} / 100 \mathrm{~g}$ magnesium, 15.2 $\mathrm{mg} / 100 \mathrm{~g}$ of sodium on fresh matter basis [22]. Therefore, using corn milk as the raw material for yogurt making can bring healthy benefits and can exploit the potential market for corn milk. Thus, this study aimed to evaluate the effects of starter concentration, ratio between corn milk and cow milk, amounts of adding sugar, temperature and time fermentation, and storage time of sweet corn milk yogurt.

\section{Materials and methods}

\subsection{Chemical and cultures}

MRS agar (De Man, Rogosa and Sharpe, Merck), MRS broth (Merck), yeast extract, beef extract, peptone, glucose, K2HPO4, diammonium citrate, MnSO4, MgSO4, Tween 80, sodium acetate, CaCO3. Sweet corn was bought from local markets in Can Tho city, Vietnam. Fresh milk was from Vinamilk (Vietnam). Five strains of Lactobacillus casei (FBLc01, FBLc02, FBLc03, FBLc01, and FBLc05) were stored at Biotechnology Research and Development Institte, Can Tho University, Vietnam..

\subsection{Fermentation procedures}

The production of sweet corn milk yogurt and experiments in this study were described in Fig. 1. The mixtures of cow milk and sweet corn milk (experiment 2, section 2.4) were boiled at $100^{\circ} \mathrm{C}$ and continuosly stirred in 10 minutes. Then, it was cooled to $30-37^{\circ} \mathrm{C}$ and inoculated with different strains of L. casei and initial cell densities (experiment 1, section 2.3). The fermentation processes were carried out at different temperatures and times (experiment 3, section 2.5). The final products were storaged at different temperatures (experiment 4, section 2.6) to evaluate the change of sweet corn milk yogurt characteristics $(\mathrm{pH}$, total acid, cell number, and sensory) in 4 weeks. 


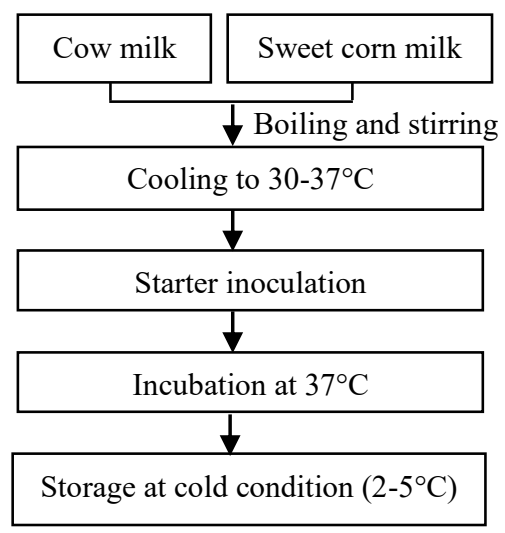

Fig. 1. The procedure to prepare yogurt from sweet corn milk

\subsection{Selection of $L$. casei strain and inoculum level}

To identify the best performed L. casei strain and suitable inoculum level for sweet corn milk fermentation. Five strains of L. casei were grown in MRS broth to increase cell concentration and diluted to the concentration of 104,106 , and 108 cells $/ \mathrm{mL}$. Then added to sweet corn milk mixture (corn/cow milk ratio of 2:8 and 3\% of sugar) and incubated for 12 $\mathrm{h}$ at $37^{\circ} \mathrm{C}$. The final fermentation products were evaluated the $\mathrm{pH}$, total acidity, cell number, and sensory.

\subsection{Effect of the ratio of corn/cow milk and sugar concentration}

To indicate the suitable ratio between corn juice, milk and sugar adding for sweet corn yogurt. Cell density was determined in section 2.3. Different ratios of corn milk and cow milk (1:9, 2:8, 3:7, 4:6, and 5:5), and percentages of adding sugar $(4,8,12$, and 16\% w/v) were investigated. The final products were analysed the $\mathrm{pH}$ value, total acidity, cell number, and sensory.

\subsection{Effect of fermentation temperature and time}

To determine the favorable fermentation temperature and time for sweet corn milk yogurt production. Used starter and sweet corn milk were the results of section 2.3 and 2.4. However, the unit experiments will be incubated at different temperatures $\left(30^{\circ} \mathrm{C}, 37^{\circ} \mathrm{C}\right.$, and $\left.40^{\circ} \mathrm{C}\right)$ and time $(6,9,12$, and $15 \mathrm{~h})$. The $\mathrm{pH}$, total acidity, cell number, and sensory of final products were evaluated as previous experiment.

\subsection{Effect of the storage condition of sweet corn milk yogurt}

To determine the suitable storage conditions for sweet corn yogurt. Sweet corn milk yogurt was stored at $0^{\circ} \mathrm{C}$ and $5^{\circ} \mathrm{C}$ in 4 weeks for evaluation of product characteristics.

\subsection{Fermentation parameters and data analysis}

The $\mathrm{pH}$ value was measured using a $\mathrm{pH}$ meter ( $\mathrm{pH}$ Mettler Toledo 320). Titratable acidity was analysed with $\mathrm{NaOH} 0.1 \mathrm{~N}$ and phenolphthalein as an indicator [23]. Cell number was estimated by the method of plate counts using MRS medium [24]. The sensory 
score was performed with 10 people using description scale (0-5) of texture, aroma, acidity, and colour followed the Vietnamese Standard 3215:79 [25]. Experimental data were processed statistically by Statgraphics Centurion XV.I software (Statpoint Technologies Inc., USA) and charted by Microsoft Excel 2013 (Microsoft Corporation, USA).

\section{Result and discussion}

\subsection{Fermentation ability of $L$. casei and inoculum cell density}

The $\mathrm{pH}$ and total acidity (TA) values are shown in Table $1 . \mathrm{pH}$ values fluctuated from 4.30 \pm 0.11 to $6.59 \pm 0.21$ and TA values were from $0.29 \pm 0.03 \%$ to $0.79 \pm 0.01 \%$. Cell numbers were varied from $9.10 \pm 0.34 \log$ cells $/ \mathrm{mL}$ to $11.49 \pm 0.45 \log$ cells $/ \mathrm{mL}$ after $12 \mathrm{~h}$ of incubation. All three criteria had a statistical difference. Generally, with the treatment had the same type of starter and the different cell density, the higher cell density was, the lower $\mathrm{pH}$ was, and TA value was high.

Table 1. Fermentation of sweet corn milk yogurt with different $L$. casei strains and cell densities.

\begin{tabular}{|c|c|c|c|c|c|}
\hline Strain & $\begin{array}{c}\text { Cell } \\
\text { number } \\
(\text { cells/mL) }\end{array}$ & pH & $\begin{array}{c}\text { Total acidity } \\
(\%)\end{array}$ & $\begin{array}{c}\text { Cell number } \\
(\log \text { cells } / \mathrm{mL})\end{array}$ & $\begin{array}{l}\text { Sensory } \\
\text { score }\end{array}$ \\
\hline FBLc01 & $10^{8}$ & $4.69 \pm 0.03^{b c}$ & $0.68 \pm 0.01^{b c}$ & $11.11 \pm 0.52^{\mathrm{ab}}$ & $14.4 \pm 0.71^{\mathrm{c}}$ \\
\hline FBLc01 & $10^{6}$ & $4.90 \pm 0.01^{\mathrm{cd}}$ & $0.64 \pm 0.03^{\mathrm{cd}}$ & $10.38 \pm 1.03^{\mathrm{cd}}$ & $\begin{array}{l}15.5 \pm \\
1.02^{\mathrm{abc}}\end{array}$ \\
\hline FBLc01 & $10^{4}$ & $6.12 \pm 0.07^{\mathrm{g}}$ & $0.41 \pm 0.01^{\mathrm{hi}}$ & $10.24 \pm 0.84^{\mathrm{cd}}$ & $\begin{array}{l}17.5 \pm \\
0.32^{\mathrm{ab}}\end{array}$ \\
\hline FBLc02 & $10^{8}$ & $4.56 \pm 0.04^{\mathrm{ab}}$ & $0.61 \pm 0.02^{\mathrm{b}}$ & $10.09 \pm 0.52^{\mathrm{d}}$ & $\begin{array}{l}16.1 \pm \\
0.98^{\mathrm{abc}}\end{array}$ \\
\hline FBLc02 & $10^{6}$ & $5.85 \pm 0.11^{\mathrm{g}}$ & $0.53 \pm 0.04^{\mathrm{hg}}$ & $9.62 \pm 0.71^{\mathrm{e}}$ & $\begin{array}{l}14.7 \pm \\
1.47^{\mathrm{abc}}\end{array}$ \\
\hline FBLc02 & $10^{4}$ & $6.59 \pm 0.21^{\mathrm{h}}$ & $0.29 \pm 0.03^{j}$ & $9.10 \pm 0.34^{\mathrm{f}}$ & $\begin{array}{l}16.7 \pm \\
0.63^{\mathrm{abc}}\end{array}$ \\
\hline FBLc03 & $10^{8}$ & $4.30 \pm 0.11^{\mathrm{a}}$ & $0.79 \pm 0.01^{\mathrm{a}}$ & $11.49 \pm 0.45^{\mathrm{a}}$ & $13.0 \pm 0.93^{\mathrm{c}}$ \\
\hline FBLc03 & $10^{6}$ & $4.63 \pm 0.08^{\mathrm{bc}}$ & $0.69 \pm 0.01^{b}$ & $11.18 \pm 0.54^{\mathrm{ab}}$ & $18.1 \pm 1.16^{\mathrm{a}}$ \\
\hline FBLc03 & $10^{4}$ & $5.95 \pm 0.13^{\mathrm{g}}$ & $0.44 \pm 0.00^{\text {ghi }}$ & $10.38 \pm 1.15^{\mathrm{cd}}$ & $18.1 \pm 1.04^{\mathrm{a}}$ \\
\hline FBLc04 & $10^{8}$ & $5.19 \pm 0.16^{\mathrm{ef}}$ & $0.57 \pm 0.01^{\mathrm{ef}}$ & $10.97 \pm 0.63^{b}$ & $\begin{array}{l}15.3 \pm \\
0.38^{\mathrm{abc}}\end{array}$ \\
\hline FBLc04 & $10^{6}$ & $5.83 \pm 0.09^{\mathrm{g}}$ & $0.46 \pm 0.01^{\mathrm{g}}$ & $10.58 \pm 0.46^{\mathrm{c}}$ & $18.1 \pm 0.71^{\mathrm{a}}$ \\
\hline FBLc04 & $10^{4}$ & $5.83 \pm 0.12^{\mathrm{g}}$ & $0.39 \pm 0.00^{\mathrm{i}}$ & $10.20 \pm 1.41^{\mathrm{cd}}$ & $\begin{array}{l}17.7 \pm \\
0.82^{\text {ab }}\end{array}$ \\
\hline FBLc05 & $10^{8}$ & $5.03 \pm 0.14^{\mathrm{de}}$ & $0.61 \pm 0.05^{\mathrm{e}}$ & $10.49 \pm 0.76^{\mathrm{c}}$ & $\begin{array}{l}16.4 \pm \\
0.91^{\mathrm{abc}}\end{array}$ \\
\hline FBLc05 & $10^{6}$ & $5.36 \pm 0.07^{\mathrm{f}}$ & $0.53 \pm 0.01^{\mathrm{f}}$ & $10.30 \pm 0.63^{\mathrm{cd}}$ & $\begin{array}{l}17.6 \pm \\
1.07^{\mathrm{ab}}\end{array}$ \\
\hline FBLc05 & $10^{4}$ & $6.52 \pm 0.21^{\mathrm{h}}$ & $0.33 \pm 0.00^{j}$ & $10.21 \pm 0.84^{\mathrm{cd}}$ & $\begin{array}{l}15.5 \pm \\
0.61^{\mathrm{abc}}\end{array}$ \\
\hline \multicolumn{2}{|c|}{ Coefficient of variation (\%) } & 6.12 & 12.21 & 11.09 & 14.16 \\
\hline
\end{tabular}


Note: Values in the table were the average values of triplications. Difference values of statistics only had meaning in the column; the average values with the same letter were not significant at 95\% probability. The suitable $\mathrm{pH}$ for yogurt is 4.1-4.6 (at this $\mathrm{pH}$ range the yogurt was firmer) and TA is $0.7-0.9 \%$ [26]. Therefore, treatments using L. casei FBLc01, FBLc02 with cell number of 108 cells $/ \mathrm{mL}$ and L. casei FBLc03 with cell numbers of 106 and 108 cells $/ \mathrm{mL}$ had suitable $\mathrm{pH}$ and TA values. However, when comparing the cell number values, treatments using L. casei FBLc01-108 cells/mL, L. casei FBLc03-108 cells/mL and L. casei FBLc03-106 cells/mL had the highest values and not significantly different. The results of sensory evaluation showed that most treatments were not statistically different. However, treatment using L. casei FBLc01108 cells $/ \mathrm{mL}$ had the lowest sensory score $(14.4 \pm 0.71 / 20)$ while the treatment using L. casei FBLc03-106 cells/mL had the highest sensory score $(18.1 \pm 1.16 / 20)$. Therefore, L. casei FBLc03-106 cells/mL was chosen for further experiments.

\subsection{The effect of corn milk/cow milk ratio and sugar concentration}

As shown in Table 2, with the same ratio between corn and cow milk, the treatments had a higher amount of sugar added, TA value was low, and $\mathrm{pH}$ was high. Besides, if the same amount of adding sugar and different corn/cow milk ratios, $\mathrm{pH}$ value had the inverse proportion with the amount of adding corn milk, when the content of corn milk was low, the $\mathrm{pH}$ value was high and TA value was low.

According to the appropriate conditions for $\mathrm{pH}$ value and TA of yogurt products ( $\mathrm{pH}$ of 4.1-4.6 and TA of $0.7-0.9 \%), 10$ treatments including $1: 9-4 \%, 2: 8-4 \%, 2: 8-8 \%, 2: 8-12 \%$, $3: 7-4 \%, 3: 7-8 \%, 4: 6-4 \%, 4: 6-8 \%, 4: 6-12 \%$, and 5:5-16\% had $\mathrm{pH}$ values around 4.21-4.60 and TA values were in the range of $0.7-0.9 \%$. Of which, the treatment of $2: 8-12 \%$ had the highest sensory score $(19.1 \pm 1.01 / 20)$ so this treatment was chosen for further experiments..

Table 2. Fermentation of sweet corn milk yogurt with different ratios of corn/cow milk and sugar concentrations.

\begin{tabular}{|c|c|c|c|c|}
\hline $\begin{array}{c}\text { Sweet corn } \\
\text { milk/cow milk }\end{array}$ & $\begin{array}{c}\text { Adding } \\
\text { sugar }(\mathbf{\%})\end{array}$ & $\mathbf{p H}$ & $\begin{array}{c}\text { Total acidity } \\
(\mathbf{\%})\end{array}$ & Sensory score \\
\hline $5: 5$ & 4 & $3.70 \pm 0.04^{\mathrm{a}}$ & $0.97 \pm 0.02^{\mathrm{a}}$ & $8.9 \pm 0.61^{\text {ef }}$ \\
\hline $5: 5$ & 8 & $4.86 \pm 0.11^{\mathrm{jk}}$ & $0.63 \pm 0.00^{\mathrm{i}}$ & $12.1 \pm 1.07^{\mathrm{de}}$ \\
\hline $5: 5$ & 12 & $4.65 \pm 0.09^{\mathrm{fghi}}$ & $0.68 \pm 0.00^{\mathrm{fg}}$ & $15.8 \pm 0.79^{\mathrm{abc}}$ \\
\hline $5: 5$ & 16 & $4.32 \pm 0.02^{\mathrm{bcd}}$ & $0.79 \pm 0.01^{\mathrm{bc}}$ & $15.3 \pm 0.57^{\mathrm{bcd}}$ \\
\hline $4: 6$ & 4 & $4.23 \pm 0.11^{\mathrm{bc}}$ & $0.81 \pm 0.02^{\mathrm{b}}$ & $8.3 \pm 0.11 \mathrm{f}$ \\
\hline $4: 6$ & 8 & $4.52 \pm 0.04^{\mathrm{fg}}$ & $0.72 \pm 0.01^{\text {ef }}$ & $13.7 \pm 0.35^{\mathrm{de}}$ \\
\hline $4: 6$ & 12 & $4.46 \pm 0.00^{\mathrm{def}}$ & $0.74 \pm 0.01^{\mathrm{de}}$ & $15.4 \pm 0.83^{\mathrm{bcd}}$ \\
\hline $4: 6$ & 16 & $4.87 \pm 0.03^{\mathrm{k}}$ & $0.64 \pm 0.00^{\mathrm{hi}}$ & $16.3 \pm 2.04^{\mathrm{abc}}$ \\
\hline $3: 7$ & 4 & $4.29 \pm 0.08^{\mathrm{bc}}$ & $0.80 \pm 0.01^{\mathrm{bc}}$ & $10.2 \pm 0.54^{\mathrm{ef}}$ \\
\hline $3: 7$ & 8 & $4.21 \pm 0.13^{\mathrm{b}}$ & $0.82 \pm 0.01^{\mathrm{b}}$ & $16.2 \pm 0.61^{\mathrm{abc}}$ \\
\hline
\end{tabular}




\begin{tabular}{|c|c|c|c|c|}
\hline $3: 7$ & 12 & $4.72 \pm 0.18^{\mathrm{ij}}$ & $0.67 \pm 0.00^{\mathrm{gh}}$ & $15.8 \pm 1.33^{\mathrm{abc}}$ \\
\hline $3: 7$ & 16 & $4.87 \pm 0.34^{\mathrm{k}}$ & $0.64 \pm 0.01^{\mathrm{h}}$ & $15.9 \pm 0.74^{\mathrm{abc}}$ \\
\hline $2: 8$ & 4 & $4.37 \pm 0.16^{\text {cde }}$ & $0.77 \pm 0.03^{\mathrm{cd}}$ & $9.1 \pm 0.23^{\text {ef }}$ \\
\hline $2: 8$ & 8 & $4.48 \pm 0.07^{\text {ef }}$ & $0.74 \pm 0.04^{\mathrm{de}}$ & $15.7 \pm 0.67^{\mathrm{bc}}$ \\
\hline $2: 8$ & 12 & $4.55 \pm 0.14^{\mathrm{gh}}$ & $0.73 \pm 0.03^{\mathrm{de}}$ & $19.1 \pm 1.01^{\mathrm{a}}$ \\
\hline $2: 8$ & 16 & $5.33 \pm 0.12^{\mathrm{l}}$ & $0.54 \pm 0.00^{\mathrm{j}}$ & $16.9 \pm 0.79^{\mathrm{abc}}$ \\
\hline $1: 9$ & 4 & $4.60 \pm 0.03^{\text {fghi }}$ & $0.70 \pm 0.01^{\text {efg }}$ & $9.9 \pm 0.30^{\text {ef }}$ \\
\hline $1: 9$ & 8 & $4.67 \pm 0.20^{\mathrm{hi}}$ & $0.68 \pm 0.02^{\mathrm{g}}$ & $17.4 \pm 0.92^{\mathrm{ab}}$ \\
\hline $1: 9$ & 12 & $4.96 \pm 0.06^{\mathrm{k}}$ & $0.62 \pm 0.02^{\mathrm{i}}$ & $19.1 \pm 1.05^{\mathrm{a}}$ \\
\hline $1: 9$ & 16 & $5.50 \pm 0.17^{\mathrm{m}}$ & $0.50 \pm 0.01^{\mathrm{j}}$ & $18.3 \pm 0.94^{\mathrm{ab}}$ \\
\hline Coefficient of variation $(\%)$ & 7.62 & 9.12 & 13.65 \\
\hline
\end{tabular}

Note: Values in the table were the average values of triplications. Difference values of statistics only had meaning in the column; the average values with the same letter were not significant at 95\% probability.

\subsection{The effect of fermentation temperature and time}

After incubation in $15 \mathrm{~h}$, all treatments reached the required values of $\mathrm{pH}$ and TA (Table 3). While the $\mathrm{pH}$ values of treaments at $37^{\circ} \mathrm{C}$ and $40^{\circ} \mathrm{C}$ were not statistically different, the $\mathrm{pH}$ value at $30^{\circ} \mathrm{C}$ was higher and had a statistical difference. At the same temperature, if products were incubated in the longer fermentation time, it had lower $\mathrm{pH}$. When the starter was added to the mixture, it needs time to adapt new environment and their enzyme system to some extent to reach the maximum growth rate [4]. In the early periods, $\mathrm{pH}$ values were high $\left(6.37\right.$ at $30^{\circ} \mathrm{C}, 5.65$ at $37^{\circ} \mathrm{C}$, and 5.56 at $\left.40^{\circ} \mathrm{C}\right)$ after $6 \mathrm{~h}$ and the amount of acid lactic was low $\left(0.36 \pm 0.01 \%\right.$ at $30^{\circ} \mathrm{C}, 0.48 \pm 0.03 \%$ at $37^{\circ} \mathrm{C}$, and $0.49 \pm 0.03 \%$ at $\left.40^{\circ} \mathrm{C}\right)$. After 12 $\mathrm{h}$, at $37^{\circ} \mathrm{C}$ and $40^{\circ} \mathrm{C}$, treatments got required $\mathrm{pH}$ and $\mathrm{TA}$ values for sweet corn milk yogurt. In the same range of fermentation time, when treatments were incubated at higher temperature it had lower $\mathrm{pH}$. At the end of fermentation period, all values had good results for the final product. The highest sensory scores belonged to treatments at $37^{\circ} \mathrm{C}$ and $40^{\circ} \mathrm{C}$ with $12 \mathrm{~h}$ and $15 \mathrm{~h}$ of fermentation. These 4 treatments had no significantly different. However, to save time and energy, treatment of $37^{\circ} \mathrm{C}$ and $12 \mathrm{~h}$ was the most suitable.

Table 3. Fermentation of sweet corn milk yogurt at different temperatures and time.

\begin{tabular}{|c|c|c|c|c|}
\hline $\begin{array}{c}\text { Temperature } \\
\left({ }^{\circ} \mathbf{C}\right)\end{array}$ & $\begin{array}{c}\text { Time } \\
(\mathbf{h})\end{array}$ & $\mathbf{p H}$ & $\begin{array}{c}\text { Total acidity } \\
(\mathbf{\%})\end{array}$ & Sensory score \\
\hline \multirow{3}{*}{30} & 6 & $6.37 \pm 0.22^{\mathrm{g}}$ & $0.36 \pm 0.01^{\mathrm{g}}$ & $7.8 \pm 0.13^{\mathrm{f}}$ \\
\cline { 2 - 5 } & 9 & $5.83 \pm 0.13^{\mathrm{h}}$ & $0.45 \pm 0.01^{\mathrm{f}}$ & $9.1 \pm 0.34^{\mathrm{ef}^{\mathrm{f}}}$ \\
\cline { 2 - 5 } & 12 & $4.82 \pm 0.21^{\mathrm{c}}$ & $0.66 \pm 0.03^{\mathrm{b}}$ & $10.8 \pm 0.24^{\mathrm{de}}$ \\
\cline { 2 - 5 } & 15 & $4.65 \pm 0.09^{\mathrm{b}}$ & $0.71 \pm 0.02^{\mathrm{b}}$ & $11.8 \pm 0.45^{\mathrm{cd}}$ \\
\hline \multirow{3}{*}{37} & 6 & $5.65 \pm 0.12^{\mathrm{e}}$ & $0.48 \pm 0.03^{\mathrm{e}}$ & $8.1 \pm 0.31^{\mathrm{f}}$ \\
\cline { 2 - 5 } & 9 & $5.30 \pm 0.14^{\mathrm{d}}$ & $0.54 \pm 0.00^{\mathrm{d}}$ & $12.9 \pm 0.23^{\mathrm{bc}}$ \\
\hline
\end{tabular}




\begin{tabular}{|c|c|c|c|c|}
\hline & 12 & $4.61 \pm 0.07^{\mathrm{b}}$ & $0.69 \pm 0.01^{\mathrm{b}}$ & $16.1 \pm 0.32^{\mathrm{a}}$ \\
\cline { 2 - 5 } & 15 & $4.49 \pm 0.11^{\mathrm{a}}$ & $0.73 \pm 0.02^{\mathrm{a}}$ & $16.4 \pm 0.21^{\mathrm{a}}$ \\
\hline \multirow{3}{*}{40} & 6 & $5.56 \pm 0.07^{\mathrm{e}}$ & $0.49 \pm 0.03^{\mathrm{e}}$ & $7.7 \pm 0.17^{\mathrm{f}}$ \\
\cline { 2 - 5 } & 9 & $5.25 \pm 0.16^{\mathrm{d}}$ & $0.56 \pm 0.04^{\mathrm{d}}$ & $13.6 \pm 0.31^{\mathrm{b}}$ \\
\cline { 2 - 5 } & 12 & $4.59 \pm 0.19^{\mathrm{b}}$ & $0.70 \pm 0.02^{\mathrm{b}}$ & $16.2 \pm 0.45^{\mathrm{a}}$ \\
\cline { 2 - 5 } & 15 & $4.45 \pm 0.05$ & $0.75 \pm 0.02^{\mathrm{a}}$ & $16.9 \pm 0.42^{\mathrm{a}}$ \\
\hline \multicolumn{2}{|r}{ Coefficient of variation (\%) } & 8.12 & 9.61 & 11.04 \\
\hline
\end{tabular}

Note: Values in the table were the average values of triplications. Difference values of statistics only had meaning in the column; the average values with the same letter were not significant at $95 \%$ probability.

\subsection{The effect of the storage condition in sweet corn milk yogurt}

$\mathrm{pH}$ values of sweet corn milk yogurt stored at $0^{\circ} \mathrm{C}$ after 1 month had not significantly change with a slight decrease, from $4.57 \pm 0.17$ (1st week) to $4.51 \pm 0.12$ (4th week) but still in the suitable range of normal yogurt (Figure 2A). The TA values also had no statistical different change during 4 weeks of storage. The final TA value was $0.73 \pm 0.03 \%$ and the cell number was at $9.86 \pm 0.61 \mathrm{log}$ cells $/ \mathrm{mL}$ (Figure 3). Although LAB almost stop all their growth at $0^{\circ} \mathrm{C}[4]$, there is little change in $\mathrm{pH}$, TA and cell density values during storage.

Normally, when temperature is around $5 \mathrm{oC}$ or lower, the latic acid fementation was not continued to produce [4]. However, if the yogurt was stored at $5^{\circ} \mathrm{C}$ in a long time, the amount of lactic acid would increase gradually day by day. At the second week of storage, the $\mathrm{pH}$ and TA values were slightly changed to $4.11 \pm 0.13$ and $0.85 \pm 0.03 \%$ (Figure $2 \mathrm{~B}$ ). The overall sensory characteristic of corn milk yogurt at second week of storage was not clearly change but the product become to bad smell and taste at the end of the third week. The TA value reached $1.21 \pm 0.04 \%$ and $\mathrm{pH}$ value dramatically decreased to $2.89 \pm 0.11$. Cell number was $10.12 \pm 0.73 \mathrm{log}$ cells $/ \mathrm{mL}$ (Figure 3 ) on the last day of 3 weeks of storage. The $\mathrm{pH}$ and acidity of corn milk yogurt produced by L. casei TISTR390 were 3.87 and $1.12 \%$, respectively, after storage at $5^{\circ} \mathrm{C}$ for 15 days [27]. Supavititpatana et al. [28] also reported that the shelf-lives of corn milk and cow milk yogurts were 14 days at $5^{\circ} \mathrm{C}$.

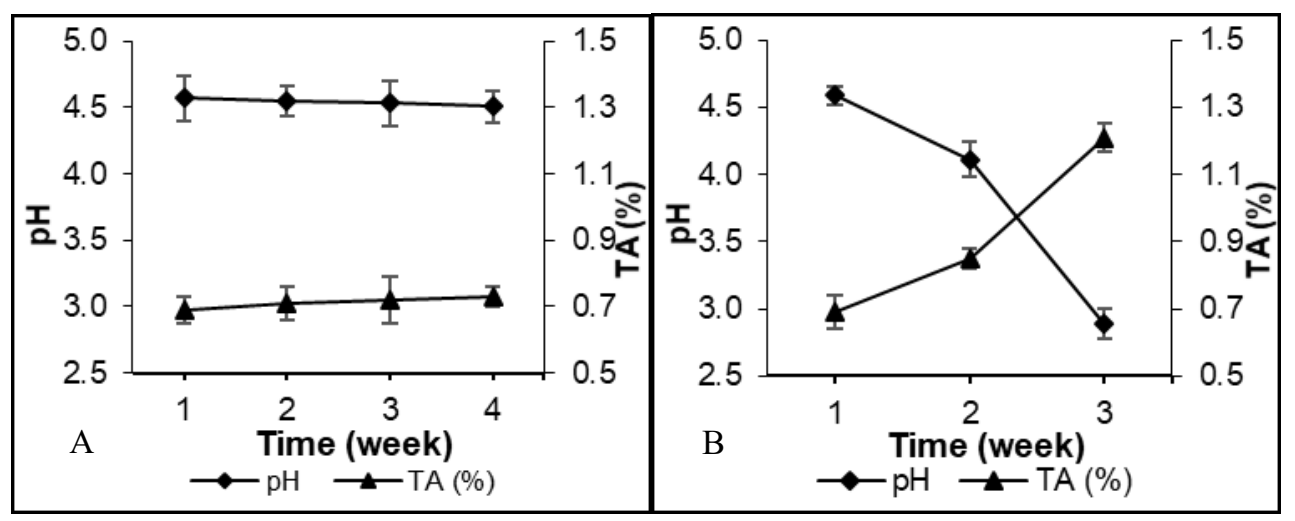

Fig. 2. The $\mathrm{pH}$ and $\mathrm{TA}$ values during storage of sweet corn milk yogurt at $0^{\circ} \mathrm{C}(\mathrm{A})$ and $5^{\circ} \mathrm{C}(\mathrm{B})$ 


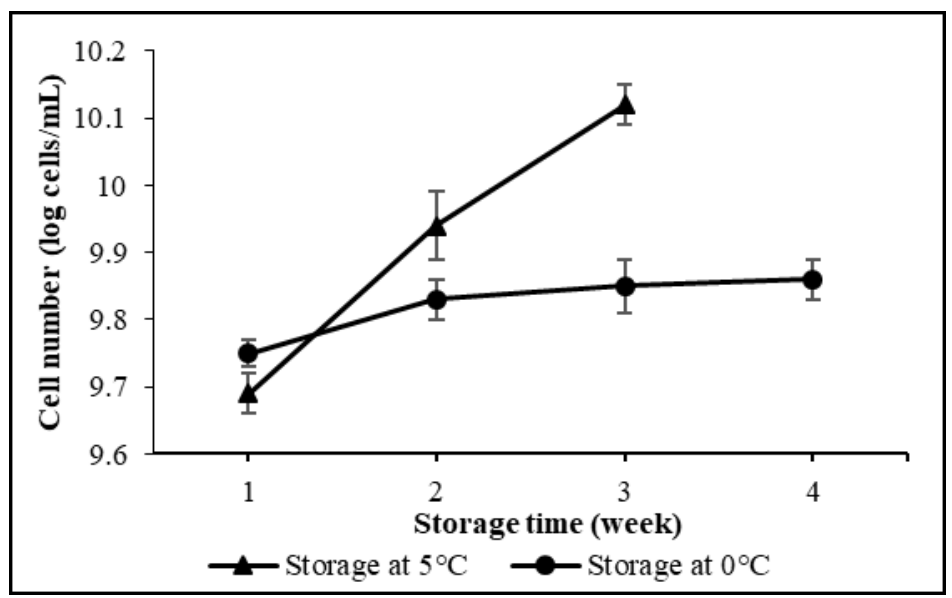

Fig. 3. Change of $L$. casei cell density in sweet corn milk yogurt storage at $0^{\circ} \mathrm{C}$ and $5^{\circ} \mathrm{C}$

\section{Conclusion}

L. casei FBLc03 has the good performance in lactic acid fermentation with initial cell density at 106 cells $/ \mathrm{mL}$. The proportion of corn milk and cow milk was 2:8 with $12 \%$ of adding sugar, and the suitable fermentation temperature was $37^{\circ} \mathrm{C}$ for $12 \mathrm{~h}$. Sweet corn milk yogurt remained acceptable taste and texture until a month at $0^{\circ} \mathrm{C}$ and 2 weeks at $5^{\circ} \mathrm{C}$.

\section{References}

1. P. Sfakianakis, C. Tzia, Foods, 3, 176 (2014).

2. V.K. Shiby, H.N. Mishra, Crit. Rev. Food Sci. Nutr. 53, 482 (2013).

3. P.H. Tsarouhas, I.S. Arvanitoyannis, Prod. Manuf. Res. 2, 11 (2014).

4. A.Y. Tamime, R.K. Robisons, Tamime and Robinson's yogurt: Science and technology (3rd ed., Woodhead Publishing LTD, Cambridge, 2007).

5. P. Walstra, T.J. Geurts, A. Noomen, A. Jellema, M.A.J.S. van Boekel. Dairy science and technology (2nd ed., CRC press, 2006).

6. N.P. Shah, Yogurt in health and disease prevention (Academic Press, 2017).

7. R.C. Chandan, Manufacturing yogurt and fermented milks (Blackwell Publishing, Ames, IA, 2006).

8. C. Chen, S. Zhao, G. Hao, H. Yu, H. Tian, G. Zhao, Int. J. Food Prop. 20, S316 (2017)

9. G. Smit, B.A. Smit, W.J. Engels, FEMS Microbiol. Rev. 29, 591 (2005).

10. D. Dimitrellou, P. Kandylis, M. Sidira, A.A. Koutinas, Y. Kourkoutas, J. Dairy Sci. 97, 4675 (2014).

11. M. Sidira, P. Kandylis, M. Kanellaki, Y. Kourkoutas, Food Chem. 201, 334 (2016).

12. D. Dimitrellou, P. Kandylis, Petrović, S. Dimitrijević-Branković, S. Lević, V. Nedović, Y. Kourkoutas, LWT, 71, 169 (2016).

13. D. Dimitrellou, P. Kandylis, Y. Kourkoutas, J. Biotechnol. 185, S79 (2014).

14. M. Sidira, G. Saxami, D. Dimitrellou, V. Santarmaki, A. Galanis, Y. Kourkoutas, J. Dairy Sci. 96, 3369 (2013). 
15. I. Bakirci, A. Kavaz, Int. J. Dairy Technol. 61, 270 (2008).

16. G. Teshome, A. Keba, Z. Assefa, B. Agza, F. Kassa, FSQM, 67, 40 (2017).

17. M.A.Fernandez, A. Marette, Adv. Nutr. 8, 155S (2017).

18. D. Mejia, E. Parrucci, Post-harvest compendium (FAO, Rome, 2005).

19. G. Swapna, G. Jadesha, P. Mahadevu, Int. J. Curr. Microbiol. App. Sci. 9, 3859 (2020).

20. A. Oktem, A. Oktem, Indian J. Plant Sci. 4, 361 (2005).

21. A. Junpatiw, K. Lertrat, K. Lomthaisong, R. Tangwongchai, Food Res. J. 20, 2219 (2013).

22. J. Makhlouf, J. Zee, N. Tremblay, A. Belanger, M.M. Michhaud, A. Gosselin, Food Res. Int. 28, 253 (1995).

23. H. Wu, X. Rui, W. Li, X. Chen, M. Jiang, M. Dong. LWT Food Sci. Technol. 63, 445 (2015).

24. Z. Huang, L. Huang, G. Xing, X. Xu, C. Tu, M. Dong, Foods 9, 299 (2020).

25. Vietnam Ministry of Science and Technology, Vietnamese Standard 3215:79 (1979).

26. T. Abee, G. Beldman, B. van de Broek, J. Houben., R. Nout, F. Rombouts, S. Schuostra, F. Voragen, J. Wouters, A. Noomen, P. Walstra. Food fermentation (Wageningen University, 1999).

27. W. Trikoomdun, B. Leenanon, Int. Food Res. J. 23, 1733 (2016)

28. P. Supavititpatana, T.I. Wirjantoro, P. Raviyan. 2010. Chiang Mai Univ. J. Nat. Sci. 9, 133 (2010). 